\title{
PENGARUH MOTIVASI KERJA GURU TERHADAP KINERJA GURU AKUNTANSI SMK DI KOTA MADIUN
}

\author{
Titin Eka Ardiana \\ Program Studi Akuntansi Fakultas Ekonomi \\ Universitas Muhammadiyah Ponorogo \\ Email: titin_ardiana@yahoo.co.id
}

\begin{abstract}
This study aims to determine the effect of motivation on teacher performance accounting work. This study uses a correlational study approach with samples taken from the accounting teacher in SMK Madiun incluster random sampling as much as 97 people. The variables of this study consists of one independent variables, namely: work motivation $(X)$ and one dependent variable is: accounting teacher performance $(Y)$. The data was collected using a structured question naire covered. Results of data collection were then analyze dusing regression analysis technique simple and multiple regression using SPSS version 20. The results show that a positive effect on work motivation on teacher performance accounting with a contribution of 80,6\%, remaining at 19,4\% accounting teacher performance is determined by factors other than research.
\end{abstract}

Keywords : motivation and teacher performance accounting

\begin{abstract}
Penelitian ini bertujuan untuk mengetahui pengaruh motivasi kerja terhadap kinerja guru akuntansi. Penelitian ini menggunakan pendekatan studi korelasional dengan sampel yang diambil dari guru akuntansi di SMK kota Madiun secara cluster random sampling sebanyak 97 orang. Variabel penelitian ini terdiri atas satu variabel bebas yaitu: motivasi kerja (X) dan satu variabel terikat yaitu: kinerja guru akuntansi (Y). Pengumpulan data dilakukan dengan menggunakan alat kuesioner berstruktur tertutup. Hasil pengumpulan data selanjutnya dianalisis menggunakan teknik analisis regresi sederhana dan regresi berganda dengan bantuan SPSS Versi 20. Hasil penelitian menunjukkan bahwa motivasi kerja berpengaruh secara positif terhadap kinerja guru akuntansi dengan kontribusi sebesar 80,6\%, selebihnya sebesar 19,4\% kinerja guru akuntansi ditentukan oleh faktor-faktor lain diluar penelitian.
\end{abstract}

Kata kunci : motivasi kerja, kinerja guru akuntansi 


\section{PENDAHULUAN}

Pengertian pendidikan menurut Undang-Undang Republik Indonesia Nomor 20 tahun 2003 tentang Sistem Pendidikan Nasional adalah usaha sadar dan terencana untuk mewujudkan suasana belajar dan proses pembelajaran agar peserta didik secara aktif mengembangkan potensi dirinya untuk memiliki kekuatan spiritual keagamaan, pengendalian diri, kepribadian, kecerdasan, akhlak mulia, serta keterampilan yang diperlukan dirinya, masyarakat, bangsa dan negara.

Peningkatan mutu pendidikan merupakan sasaran pembangunan di bidang pendidikan nasional dan merupakan bagian integral dari upaya peningkatan kualitas manusia Indonesia secara menyeluruh. Pemerintah, dalam hal ini Menteri Pendidikan Nasional telah mencanangkan "Gerakan Peningkatan Mutu Pendidikan" pada tanggal 2 Mei 2002, dan lebih terfokus lagi, setelah diamanatkan dalam Undang-Undang Republik Indonesia No 20 Tahun 2003 Tentang Sistem Pendidikan Nasional, bahwa Pendidikan nasional berfungsi mengembangkan kemampuan dan membentuk watak serta peradaban bangsa yang bermartabat dalam rangka mencerdaskan kehidupan bangsa, bertujuan untuk berkembangnya potensi peserta didik agar menjadi manusia yang beriman dan bertakwa kepada Tuhan Yang Maha Esa, berakhlak mulia, sehat, berilmu, cakap, kreatif, mandiri, dan menjadi warga negara yang demokratis serta bertanggung jawab.

Salah satu permasalahan pendidikan yang dihadapi oleh bangsa Indonesia adalah rendahnya mutu pendidikan pada setiap jenjang dan satuan pendidikan, khususnya pendidikan dasar dan menengah. Berbagai usaha telah dilakukan untuk meningkatkan mutu pendidikan nasional, misalnya pengembangan kurikulum nasional dan lokal, peningkatan kompetensi guru melalui pelatihan, pengadaan buku dan alat pelajaran, pengadaan dan berbaikan sarana dan prasarana pendidikan, dan meningkatkan manajemen sekolah.

Pendapat Mulyasa (2004:120) "Para pegawai (guru) akan bekerja dengan sungguh-sungguh apabila memiliki motivasi yang tinggi. Apabila memiliki motivasi yang positif, ia akan memperlihatkan minat, mempunyai perhatian, dan ingin ikut serta dalam suatu tugas atau kegiatan". Sesuai dengan pendapat tersebut, guru yang masih kurang berhasil dalam mengajar dikarenakan mereka kurang termotivasi untuk mengajar sehingga berdampak terhadap menurunnya produktivitas atau kinerja guru.Untuk itu diperlukan peran kepala sekolah untuk memotivasi para guru untuk meningkatkan kinerjanya.

Mutu pendidikan di tingkat satuan pendidikan dapat ditunjukkan dengan adanya fenomena sekolah-sekolah yang memiliki keunggulan dan kompetitif. Salah satu indikasi sekolah yang memiliki keunggulan dan kompetitif adalah adanya tampilan sikap dan perilaku para siswanya sesuai dengan norma yang berlaku dan adanya peningkatan prestasi belajar siswa yang salah satunya dapat dilihat dari persentase kelulusan di atas standar nasional.

Guru merupakan salah satu komponen yang menempati posisi sentral dan sangat strategi dalam sistem pendidikan. Guru merupakan faktor yang dominan dalam kaitannya dengan peningkatan kualitas pendidikan, karena guru merupakan bagian yang tidak terpisahkan dari sistem pendidikan 
secara keseluruhan yang terlibat langsung dalam proses belajar mengajar, gurulah yang berperan langsung dalam mengajar dan mendidik. Sehubungan dengan itu, perlu dilakukan berbagai program untuk meningkatkan kualitas kinerja guru dalam mengembangkan aspek-aspek pendidikan dan pembelajaran.

Banyak faktor yang mempengaruhi kinerja, antara lain adalah lingkungan, perilaku manajemen, desain jabatan, penilaian kinerja, umpan balik dan administrasi pengupahan (Tempe dalam Supardi, 2014: 50). Kinerja seseorang sangat dipengaruhi oleh faktor kemampuan (ability), motivasi (motivation), dan kesempatan (opportunity), yaitu performance artinya kinerja merupakan fungsi dari kemampuan, motivasi dan kesempatan (Robbins \& Judge, 2012: 281). Kinerja guru dapat ditunjukkan dari kemampuan guru dalam menguasai kompetensi yang dipersyaratkan, yakni kompetensi pedagogik, kompetensi kepribadian, kompetensi sosial, dan kompetensi profesional (Undang-Undang Nomor 14 Tahun 2005).

Sebagai tenaga profesional kependidikan guru memiliki motivasi kerja yang berbeda antara guru yang satu dengan lainnya. Hal ini kelak akan berakibat adanya perbedaan kinerja guru dalam meningkatkan mutu pendidikan. Herzberg (dalam bukunya Prof. Dr. J. Winardi, SE) menyatakan bahwa "Motivasi kerja bukanlah dimensi tunggal, tetapi tersusun dalam dua faktor, yaitu: faktor motivator (satisfier) dan faktor hygiene". Faktor motivator adalah faktor yang menyebabkan terjadinya kepuasan kerja, seperti prestasi kerja, pengakuan, kemajuan, perasaan bahwa yang mereka kerjakan penting dantanggung jawab. Faktor hygiene adalah faktor yang bersifat ekstrinsik, seperti kebijakan administrasi, supervisi, hubungan dengan teman kerja, gaji, rasa aman dalam pekerjaan, kehidupan pribadi, kondisi kerja dan status. Motivasi kerja guru merupakan faktor penting dalam peningkatan kinerja guru karena sebagai pendorong utama setiap guru melaksanakan tugas profesinya sesuai ketentuan yang berlaku.

Berdasarkan observasi yang dilakukan di lapangan bahwa selama ini kunjungan kelas yang dilakukan oleh kepala sekolah belum optimal sehingga kepala sekolah belum bisa melihat kinerja guru dan masalah yang dihadapi di dalam kelas secara lebih dalam. Selain itu, hampir di setiap sekolah beberapa guru tidak mempersiapkan perangkat pengajaran dengan lengkap misalnya rencana pelaksanaan harian, presensi, kisi-kisi soal, program perbaikan, laporan akhlak, analisis KKM. Dengan demikian dapat disimpulkan bahwa rendahnya motivasi kerja guru akan berdampak pada rendahnya hasil kinerja guru yang dapat berimplikasi kepada rendahnya hasil belajar siswa. Oleh karena itu saya tertarik untuk melakukan sebuah penelitian dengan melihat tingkat kinerja guru dengan judul "Pengaruh Motivasi Kerja Guru terhadap Kinerja Guru Akuntansi SMK di Kota Madiun"

\section{KAJIAN TEORI DAN PENGEMBANGAN HIPOTESIS}

\section{Kinerja}

Kinerja suatu organisasi sangat dipengaruhi oleh kinerja karyawan, sedangkan untuk meningkatkan kinerja karyawan sangat erat kaitannya dengan motivasi dari karyawan itu sendiri. Kinerja adalah perilaku seseorang yang membuahkan hasil kerja tertentu setelah memenuhi sejumlah persyaratan (Uno \& Lamatenggo, 2014: 63). Banyak faktor yang memengaruhi kinerja, antara lain adalah lingkungan, 
perilaku manajemen, desain jabatan, penilaian kinerja, umpan balik dan administrasi pengupahan (Tempe dalam Supardi, 2014: 50).

Kebijakan kinerja karyawan menurut Prawirosentono (1999) menyatakan bahwa "Performance adalah yang dicapai seseorang atau sekelompok orang dalam organisasi sesuai dengan tanggung jawab masingmasing dalam rangka mencapai tujuan organisasi bersangkutan secara royal tidak melanggar hukum dan sesuai dengan moral dan etika".

\section{Kinerja Guru}

Menurut Clewes (2003: 69-85) menyatakan bahwa "The lecturer or teacher performance is an important factor. The students are the prime evaluator of the teacher performance" (performa dosen atau guru merupakan faktor penting, para siswa adalah evaluator utama dari kinerja guru) Kinerja guru merupakan kemampuan dan keberhasilan guru dalam melaksanakan tugastugas pembelajaran (Supardi, 2014: 23).

Kinerja guru adalah hasil kerja guru yang terefleksi dalam cara merencanakan, melaksanakan dan menilai proses belajar mengajar yang intensitasnya dilandasi oleh etos kerja, serta disiplin profesional dalam proses pembelajaran (Uno, 2014: 86).

Menurut Mangkunegara menyatakan bahwa kinerja yang berkenaan dengan profesi keguruan merupakan perilaku nyata yang ditunjukkan guru pada waktu memberikan pelajaran pada siswanya. Kinerja guru dapat ditunjukkan dari kemampuan guru dalam menguasai kompetensi yang dipersyaratkan, yakni kompetensi pedagogik, kompetensi kepribadian, kompetensi sosial, dan kompetensi profesional (Undang-Undang Nomor 14 Tahun 2005).

\section{Kinerja Guru Akuntansi dalam Proses Belajar Mengajar}

Peran pengajar dipengaruhi oleh penguasaan ilmu pengetahuan yang dimilikinya, cara memberikan materi pelajaran, frekuensi memberikan pengajaran dan sebagainya. Menurut Hadiyanto dan Subiyanto (2003: 8) dijelaskan bahwa iklim pembelajaran yang kondusif antara lain dapat mendukung: (1) interaksi yang bermanfaat di antara peserta didik, (2) memperjelas pengalaman-pengalaman guru dan peserta didik, (3) menumbuhkan semangat yang memungkinkan kegiatan-kegiatan di kelas berlangsung dengan baik, dan (4) mendukung saling pengertian antara guru dan peserta didik.

Menurut Nguni et al., (2006: 145177) menyatakan bahwa "teachers who are satisfied with their job are more enthusiastic and interested in devoting more energy and time to student achievement" (guru yang puas dengan pekerjaan mereka lebih antusias dan tertarik untuk mencurahkan lebih banyak energi dan waktu dengan prestasi akademik siswa).

\section{Motivasi}

Motivasi berasal dari kata motif yang dapat diartikan sebagai kekuatan yang terdapat dalam diri individu, yang menyebabkan individu tersebut bertindak atau berbuat. Motivasi tidak dapat diamati secara langsung, tetapi dapat diinterprestasikan dalam tingkah lakunya, berupa rangsangan, dorongan, atau pembangkit tenaga munculnya suatu tingkah laku (Uno, 2007).

Motivasi adalah pemberian daya penggerak yang menciptakan kegairahan kerja seseorang, agar mereka mau bekerja sama, bekerja efektif dan terintegrasi dengan 
segala daya upayanya untuk mencapai kepuasan (Hasibuan, 2009: 219).

Robbins dalam Riduwan (2010: 147) berpendapat bahwa motivasi kerja guru diukur dalam dua dimensi, yaitu motivasi eksternal dan motivasi internal. Motivasi eksternal meliputi: hubungan antarpribadi, penggajian atau honorarium, supervisi kepala sekolah, dan kondisi kerja. Motivasi internal meliputi: dorongan untuk bekerja, kemajuan dalam karier, pengakuan yang diperoleh, rasa tanggung jawab dalam pekerjaan, minat terhadap tugas, dan dorongan untuk berprestasi.

Menurut Moekijat (2002) menyatakan bahwa motivasi adalah suatu daya pendorong atau perangsang untuk melakukan sesuatu.

\section{Motivasi Kerja}

Pandangan kerja dan bekerja dewasa ini, bukanlah seperti pandangan konservatif yang menyatakan bahwa kerja jasmaniah adalah bentuk hukuman sehingga tidak disukai orang. Akan tetapi dewasa ini, kerja dan bekerja sudah menjadi kebutuhan.

Menurut Mangkunegara (2011: 93) motivasi merupakan dorongan yang timbul pada diri seseorang yang menggerakkan untuk melakukan sesuatu. Guru yang mempunyai motivasi kerja yang tinggi akan setantiasa bekerja keras untuk mengatasi segala jenis permasalahan yang dihadapi dengan harapan mencapai hasil yang lebih baik.

Menurut Steyn (2002: 251-254) "argues that effective principals are able to create an ethos that generates motivated and successful teachers and stimulated and inspired learners in an effective school setting" (kepala sekolah yang efektif mampu menciptakan etos, menghasilkan guru untuk termotivasi dan sukses serta peserta didik yang dirangsang agar terinspirasi dalam pengaturan sekolah yang efektif).

\section{Hakikat Motivasi Kerja Guru}

Motivasi kerja tidak hanya berwujud kepentingan ekonomis saja, tetapi biasanya juga berbentuk kebutuhan psikis untuk lebih melakukan pekerjaan secara aktif. Menurut Dimyati (2006) "motivasi adalah dorongan mental yang menggerakkan dan mengarahkan perilaku manusia". Motivasi sering kali dikatakan menjadi kunci bagi kreativitas kerja. Kreativitas kerja dapat ditingkatkan dengan motivasi kerja yang tinggi, pengetahuan dan keahlian dalam melakukan tugas dan peran positif yang dimiliki seseorang.

\section{HIPOTESIS}

Pengembangan hipotesis yang dikembangkan dalam penelitian ini adalah sebagai berikut:

$\mathbf{H}_{\mathbf{1}}$ : Motivasi kerja berpengaruh positif terhadap kinerja guru akuntansi.

\section{METODE PENELITIAN}

\section{Populasi penelitian}

Populasi dalam penelitian ini adalah lembaga penelitian yaitu seluruh sekolah baik negeri atau swasta yang berada di wilayah Kota Madiun. Adapun lembaga pendidikan di wilayah Kota Madiun sebanyak 43 lembaga yang terdiri dari SMA Negeri dan Swasta sebanyak 17 lembaga dan SMK Negeri dan Swasta sebanyak 26 lembaga.

\section{Sampel Penelitian}

Untuk pemilihan sampel yang digunakan pada penelitian ini berjumlah 5 sekolah yaitu SMK Negeri 2 Madiun, SMK Negeri 5 Madiun, SMK St. Bonaventura 1 Madiun, SMK Tamansiswa 2 Madiun dan SMK PGRI 4 Madiun. Obyek pada penelitian 
ini adalah guru-guru SMK di Kota Madiun, jumlah sampel yang ditemukan adalah berjumlah 97 orang dibulatkan menjadi 100 orang. Sehingga diperoleh jumlah sampel sebanyak 100 orang.

Alat pengumpulan data dalam penelitian ini menggunakan teknik tidak langsung. Angket merupakan alat pengumpulan data dalam bentuk formulir yang dan disebarkan untuk menjaring informasi-informasi mengenai sesuatu yang terdiri dari pertanyaan-pertanyaan untuk dijawab oleh responden secara terperinci.

\section{Definisi Operasional dan Pengukuran Variabel}

\section{Motivasi Kerja Guru}

Menurut Mangkunegara (2011: 93) mendefinisikan motivasi merupakan dorongan yang timbul pada diri seseorang yang menggerakkan untuk melakukan sesuatu. Guru yang mempunyai motivasi kerja yang tinggi akan setantiasa bekerja keras untuk mengatasi segala jenis permasalahan yang dihadapi dengan harapan mencapai hasil yang lebih baik. Indikator motivasi kerja guru yaitu: (a) Kebutuhan akan berprestasi, (b) Peluang untuk berkembang, (c) Kebanggaan terhadap pekerjaan sendiri, (d) Kebutuhan akan pengakuan, dan (e) Gaji yang diterima.

\section{Kinerja Guru Akuntansi}

Menurut Rusman (2006) menyatakan bahwa berkenaan dengan kepentingan penilaian kinerja guru, georgia department of education telah mengembangkan teacher performance assesment yang kemudian dimodifikasi oleh Depdiknas menjadi Alat Penilaian Kinerja Guru (APKG) yang dikembangkan oleh proyek Pengembangan Pendidikan Dasar dan Menengah. Indikator tersebut adalah: (1) rencana pengajaran, (2) pelaksanaan pengajaran, (3) hubungan antar pribadi, dan (4) evaluasi.

\section{Tehnik Analisis}

Dalam penelitian ini untuk mengolah data dari hasil penelitian ini dengan menggunakan Analisis Inferensial (kuantitatif). Analisis data dilakukan dengan bantuan Metode Regresi Linier Sederhana. Regresi linier sederhana digunakan untuk mendapatkan hubungan matematis dalam bentuk suatu persamaan antara variabel tak bebas tunggal dengan variabel bebas tunggal. Regresi linier sederhana hanya memiliki satu peubah yang dihubungkan dengan satu peubah tidak bebas (Alan, 2012).

Analisis regresi berguna untuk mengetahui besarnya pengaruh antara variabel motivasi kerja terhadap variabel kinerja guru. Dari data kuesioner yang telah ditabulasikan dan dilakukan analisis dengan bantuan program SPSS versi 20 yang dirumuskan sebagai berikut:

$$
\mathrm{Y}=\mathrm{a}+\mathrm{b} 1 \mathrm{X}
$$

Keterangan :

$\mathrm{Y} \quad=$ Kinerja guru akuntansi,

a $=$ Konstanta,

b1 = Koefisien regresi,

$\mathrm{X}=$ Variabel motivasi kerja

\section{Uji Hipotesis}

Dalam penelitian ini untuk pengujian hipotesis menggunakan Uji t. Uji t adalah uji parsial yang digunakan untuk menguji keterkaitan antara variabel bebas secara individual dengan variabel terikat (Santoso, 2001).

\section{Uji Asumsi Klasik}

Untuk mendapatkan model regresi yang tidak bias maka perlu dilakukan uji asumsi klasik meliputi: uji multikolinearitas, autokorelasi dan heterokedastisitas (Ghozali, 2011)

JURNAL AKUNTANSI DAN PAJAK, VOL. 17, NO. 02, JANUARI 2017 - 19 


\section{HASIL DAN PEMBAHASAN}

\section{Analisis Regresi Linier Sederhana}

Analisis regresi berguna untuk mengetahui besarnya pengaruh antara variabel motivasi kerja terhadap variabel kinerja guru. Dari data kuesioner yang telah ditabulasikan dan dilakukan analisis dengan bantuan program SPSS versi 20 yang dirumuskan sebagai berikut:

$$
\mathrm{Y}=\mathrm{a}+\mathrm{b} 1 \mathrm{X}
$$

Keterangan :

$\mathrm{Y}=$ Kinerja guru akuntansi,

$\mathrm{a}=$ Konstanta,

b1 = Koefisien regresi,

$\mathrm{X}=$ Variabel motivasi kerja

Berikut ini dijelaskan pengaruh variabel motivasi kerja terhadap variabel kinerja guru akuntansi melalui pengujian Regresi Linier Sederhana sebagai berikut:

\section{Tabel 1}

Analisis Regresi Linier Sederhana

\begin{tabular}{llll}
\hline & \multicolumn{2}{l}{$\begin{array}{l}\text { Unstandardized } \\
\text { Coefficients }\end{array}$} & \multicolumn{1}{l}{$\begin{array}{l}\text { Standardized } \\
\text { Coefficients }\end{array}$} \\
Model & $\mathrm{B}$ & $\begin{array}{l}\text { Std. } \\
\text { Error }\end{array}$ & Beta \\
\hline \multicolumn{1}{c}{ (Constant) } & 103.459 & .223 & \\
1 Motivasi & 0.406 & .047 & .898 \\
\multicolumn{1}{l}{ Kerja (X) } & & & \\
\hline
\end{tabular}

Sumber : Hasil Pengolahan Data dengan SPSS

Dari tabel tersebut dapat dijelaskan sebagai berikut:

1. Koefisien regresi (b0) sebesar 103,459. Hal ini memiliki pengertian bahwa apabila tidak terjadi peningkatan variabel motivasi kerja (konstan) maka kinerja guru akuntansi sebesar 103,459 satu satuan dengan asumsi variabel lain tetap. Dengan kata lain tanpa adanya motivasi kerja, kinerja guru akuntansi sebesar 3,459.
2. Koefisien regresi (b1) sebesar 0,406. Hal ini memiliki pengertian bahwa apabila terjadi peningkatan variabel motivasi kerja sebesar satu satuan maka kinerja guru akuntansi akan naik sebesar 0,406 satu satuan dengan asumsi variabel lain tetap.

Besarnya keragaman motivasi kerja (X) yang dapat dijelaskan oleh variabel kinerja guru akuntansi (Y) adalah 0, $806(R$ Square) atau sebesar $80,6 \%$ sedangkan halhal lain yang juga berpengaruh terhadap kinerja guru akuntansi diantaranya sarana prasarana sekolah, lingkungan kerja sebesar $19,4 \%$

Peneliti dalam peneltian ini mengadakan pembahasan terhadap hasil uji hipotesis diperoleh gambaran sebagai berikut: Besarnya keragaman X terhadap Y sebesar 0, 806 ( $R$ Square) atau sebesar 80,6\%. Hal ini menunjukkan bahwa antara motivasi kerja (X) terhadap kinerja guru akuntansi SMK di Kota Madiun (Y) ada pengaruh besar dan positif. Sedangkan sisanya sebesar 19,4\% dipengaruhi oleh hal-hal diluar motivasi kerja. Oleh karena itu seharusnya motivasi guru mendapat perhatian yang paling serius dibanding variabel bebas yang lain.

Variabel motivasi kerja yang menjadi variabel bebas dalam penelitian ini memiliki pengaruh yang signifikan dalam meningkatkan kinerja guru akuntansi SMK di Kota Madiun. Hal ini disebabkan tumbuhnya rasa tanggung jawab dan pemahaman tujuan atau makna dari kerja yang selama ini dijalani, sehingga kinerja guru akuntansi semakin meningkat di sekolah menengah kejuruan (SMK) Kota Madiun. Meskipun tanpa adanya motivasi kerja, kinerja dari guru akuntansi di SMK di Kota Madiun sudah baik. Hal ini dapat dilihat pada nilai koefisien regresi untuk variabel konstan sebesar 103,459.

\section{Pengujian secara Simultan (Uji F)}


Pengujian hipotesis ini dimaksudkan untuk mengetahui sebuah tafsiran parameter untuk mengukur seberapa besar pengaruh dari variabel motivasi kerja terhadap variabel kinerja guru akuntansi.

Tabel 2

Hasil Uji F Motivasi Kerja (X)

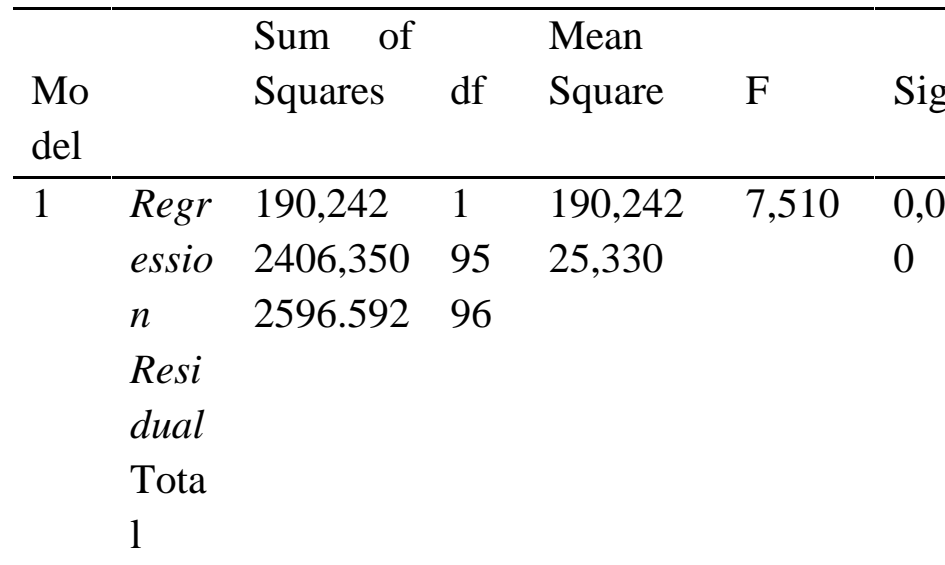

Sumber : Hasil Pengolahan Data dengan SPSS

Sesuai keterangan tersebut di atas menunjukkan bahwa $\mathrm{F}$ hitung $=7,510$ sedangkan $\mathrm{F}$ tabel 3,940 (sesuai lampiran). Jika $\mathrm{F}$ hitung $>\mathrm{F}$ tabel dengan tingkat kesalahan 0,000 maka hipotesis penelitian ini menolak Ho. Diterima artinya variabel motivasi kerja secara simultan berpengaruh terhadap kinerja guru akuntansi.

\section{Uji Parsial (Uji t)}

Uji t juga disebut dengan uji parsial, pengujian ini bertujuan untuk menguji signifikansi hasil dari uji regresi linier sederhana. Pembuktian hipotesis ini yaitu dengan memperhatikan $\mathrm{t}$ hitung dan signifikan. Untuk uji t didapat hasil sesuai tabel 3 hasil uji t berikut ini.

Tabel 3

Hasil Uji t

\begin{tabular}{llll}
\hline Model & & T & Sig. \\
\hline \multirow{3}{*}{1} & Constant & 8,450 & 0,000 \\
& Motivasi & 3,677 & 0,002 \\
& kerja (X) & & \\
\hline
\end{tabular}

Sumber : Hasil Pengolahan dari Program SPSS

Sesuai data yang terdapat dalam tabel 3 hasil uji t tersebut di atas dijelaskan dengan uraian sebagai berikut:

Berdasarkan hasil nilai $t$ hitung sebesar 3,677 dan $\mathrm{t}$ tabel sebesar 1,161 (t hitung $>\mathrm{t}$ tabel). Kemudian dari tingkat signifikan $\mathrm{t}$ sebesar 0,002 lebih kecil dari ig $0,05(0,017<0,05)$ maka hipotesis penelitian ini menolak Ho. Yang berarti secara parsial ,0@motivasi kerja memiliki pengaruh yang signifikan terhadap kinerja guru akuntansi.

\section{KESIMPULAN DAN SARAN Kesimpulan}

Motivasi kerja mempunyai pengaruh yang signifikan terhadap kinerja guru akuntansi di SMK Kota Madiun, sesuai hasil analisis determinasi $\mathrm{R}^{2} \quad(R$ Square). Ini menunjukkan bahwa antara motivasi kerja (X) dengan kinerja guru akuntansi SMK di Kota Madiun (Y) ada pengaruh positif, dan sisanya dipengaruhi oleh variabel-variabel lain.

Dalam uji analisis multi variabelkorelasi dapat diketahui bahwa variabel bebas $\mathrm{X}$ (motivasi kerja) menunjukkan bahwa motivasi kerja mempunyai pengaruh positif terhadap kinerja guru akuntansi SMK Kota Madiun. Penelitian ini juga memberikan deskripsi yang jelas bahwa dengan motivasi kerja yang tinggi akan mempengaruhi kinerja guru akuntansi SMK di kota Madiun.

\section{Saran}

Berdasarkan hasil penelitian, maka dapat disarankan beberapa hal, khususnya kepada para guru Akuntansi serta pihak SMK di kota Madiun sebagai berikut:

1. Guru hendaknya terus meningkatkan kinerjanya dalam menjalankan tugas di sekolah sehingga profesionalitas dan kemampuannya dalam dunia pendidikan semakin bertambah. Hal ini dapat 
dilakukan dengan melaksanakan segala peraturan atau ketentuan yang berlaku di sekolah, mengikuti berbagai kegiatan baik melalui pendidikan formal atau non formal, seperti seminar, lokakarya, maupun mengikuti program pendidikan lebih lanjut.

2. Sekolah hendaknya menyediakan fasilitas yang memadai dalam pembelajaran sehingga dapat mendukung peningkatan kinerja guru akuntansi SMK di kota Madiun.

\section{DAFTAR PUSTAKA}

Alan. 2012. Analisis Regresi Linear Sederhana. Http://www.scrib.com.23 Oktober.

Clewes, D. 2003. "A student-centred conceptual model of service quality in higher education". Quality in Higher Education, 9 (1): 69-85.

Dimyati dan Mudjiono, 2006. Belajar dan Pembelajaran. Jakarta: Rineka Cipta

Ghozali, Imam. 2011. Aplikasi Analisis Multivariate dengan Program SPSS. Semarang: Badan Penerbit Universitas Diponegoro.

Hadiyanto \& Subiyanto. 2003. Pengembalian Kebebasan Guru untuk Mengkreasi Iklim Kelas Dalam Manajemen Berbasis Sekolah. Jurnal Pendidikan dan Kebudayaan no. 040. Januari 2003. Diambil pada tanggal 6 September $2006 \quad$ dari http://www.depdiknas.go.id.

Hasibuan, M.S.P. 2009. Manajemen: Dasar, Pengertian Dan Masalah. (Edisi revisi). Jakarta: Bumi Aksara.
Mangkunegara, Anwar Prabu. 2007. Evaluasi Kinerja MSDM. Bandung: PT. Refika Aditama.

Mangkunegara, Anwar Prabu. 2011. Manajemen Sumber Daya Manusia Perusahaan. Bandung: PT. Remaja Rosdakarya Aditama.

Moekijat. 2002. Dasar-dasar Motivasi. Jakarta: Penerbit Pionir Jaya.

Mulyasa. 2004. Manajemen Berbasis Sekolah: Konsep, Strategi dan Implementasi. Bandung: PT.Remaja Rosdakarya

Nguni, S., Sleegers, P. \& Denessen, E. 2006. Transformational and transactional leadership effects on teachers' job satisfaction, organizational commitment, and organizational citizenship behavior in primary schools: The Tanzanian case. School Effectiveness and School Improvement, 17: 145-177.

Prawirosentono, S. 1999. Kebijakan Kinerja Karyawan. Yogyakarta: BPFE.

Riduwan. (2010). Metode Dan Teknik Menyusun Proposal Penelitian. (Cetakan ketiga). Bandung: Alfabeta.

Robbins, S.P. \& Judge, T.A. 2012. Perilaku Organisasi (Organizational Behavior). Buku 1. Edisi kedua belas. Alih Bahasa: Diana Angelica, Ria Cahyani, dan Abdul Rosyid. Jakarta: Salemba Empat.

Rusman. 2006. Pendekatan dan Model Pembelajaran. Bandung:Universitas Pendidikan Indonesia. 
Singgih, Santoso. 2001."SPSS: Mengolah Data Statistik secara Profesional", Jakarta: Penerbit PT Elex Media Komputindo Kelompok Gramedia, Anggota IKAPI.

Steyn, G.M. 2002. The changing Principalship in South African Schools. Educare, 32 (1\&2): 251-254.

Supardi. 2014. Kinerja guru. Jakarta: PT RajaGrafindo Persada.

Undang-Undang RI No. 20 Tahun 2003.

Tentang Sistem Pendidikan Nasional. Bandung: Penerbit Citra Umbara.

Undang-Undang Republik Indonesia Nomor 14 Tahun 2005 tentang Guru dan Dosen. Jakarta.

Uno, H.B. 2014. Teori motivasi \& pengukurannya: analisis di bidang pendidikan. Jakarta: Bumi Aksara.

Uno, H.B., \& Lamatenggo, N. 2007. Teori kinerja dan pengukurannya. Jakarta: Bumi Aksara.

Winardi, J. 2001. Motivasi dan Pemotivasian dalam Manajemen.Jakarta : PT Raja Grafindo Persada. 